\title{
Reservoir quality of Hawaz formation, J oil field, concession NC186, NW Murzuq basin, SW Libya
}

\author{
A. K. Mohamed ${ }^{a} *$ A. A. Kashlaf ${ }^{\text {b }}$ \\ ${ }^{a}$ Dept. of Geology, Faculty of Science, Mansoura Univ., Egypt \\ ${ }^{\mathrm{b}}$ Dept. of Engineering geology, Faculty of natural resources, Zawia Univ., Libya
}

Received: 14 February 2014 / Accepted: 15 May 2014

* Corresponding author: (Tel: +20.01000567331. email: kashlafa@yahoo.com)

\begin{abstract}
The present paper deals with evaluation of petro-physical parameters of Hawaz Formation at $\mathbf{J}$ oil field, Concession NC186 in Murzuq basin through the analysis of well-log data available for ten exploratory wells, distributed in J oil field. A comprehensive formation evaluation has been applied through numbers of cross-plots and using their output parameters as input data for interactive petro-physics software (IP) in order to evaluate the lithological constituents and fluid saturations. The litho-saturation cross-plot indicated that the Hawaz Formation consists of sandstones with few shale. These sandstones are generally fine to very fine grains but occasionally coarse to very coarse grained. Generally coursing upward sequence is indicated. The litho-saturation cross-plots also illustrated that horizon $\mathrm{H} 4$ and $\mathrm{H} 5$ are the main reservoirs in Hawaz formation
\end{abstract}

Keywords: Hawaz Formation, J field, well logging, petro-physical parameters

\section{Introduction}

Murzuq Basin is located on the North African Platform (Fig. 1), covers an area of some 350,000 $\mathrm{km}^{2}$, extending southwards into Niger [1]. The present-day borders of the basin are defined by erosion resulting from multiphase tectonic uplifts. It is not a sedimentary basin in the normally accepted sense, and could more accurately be described as an erosional remnant of a much larger Palaeozoic and Mesozoic sedimentary basin which originally extended over much of North Africa [2]. The flanks comprise the Tihemboka high to the $\mathrm{W}$, the Tibesti high to the SE, and the Gargaf and Atshan highs to the N and NW. These uplifts were generated by various tectonic events ranging from middle Palaeozoic to Tertiary times, but the main periods of uplift took place during Middle Cretaceous to Early Tertiary Alpine movements.

The present-day Murzuq Basin contains a maximum sedimentary fill of about $4000 \mathrm{~m}$. Davidson et al. [2] pointed out that, despite successive erosive episodes during several phases of uplift and erosion throughout the history of the basin, the maximum sedimentary thickness probably never exceeded $5000 \mathrm{~m}$ at any single point in time. 


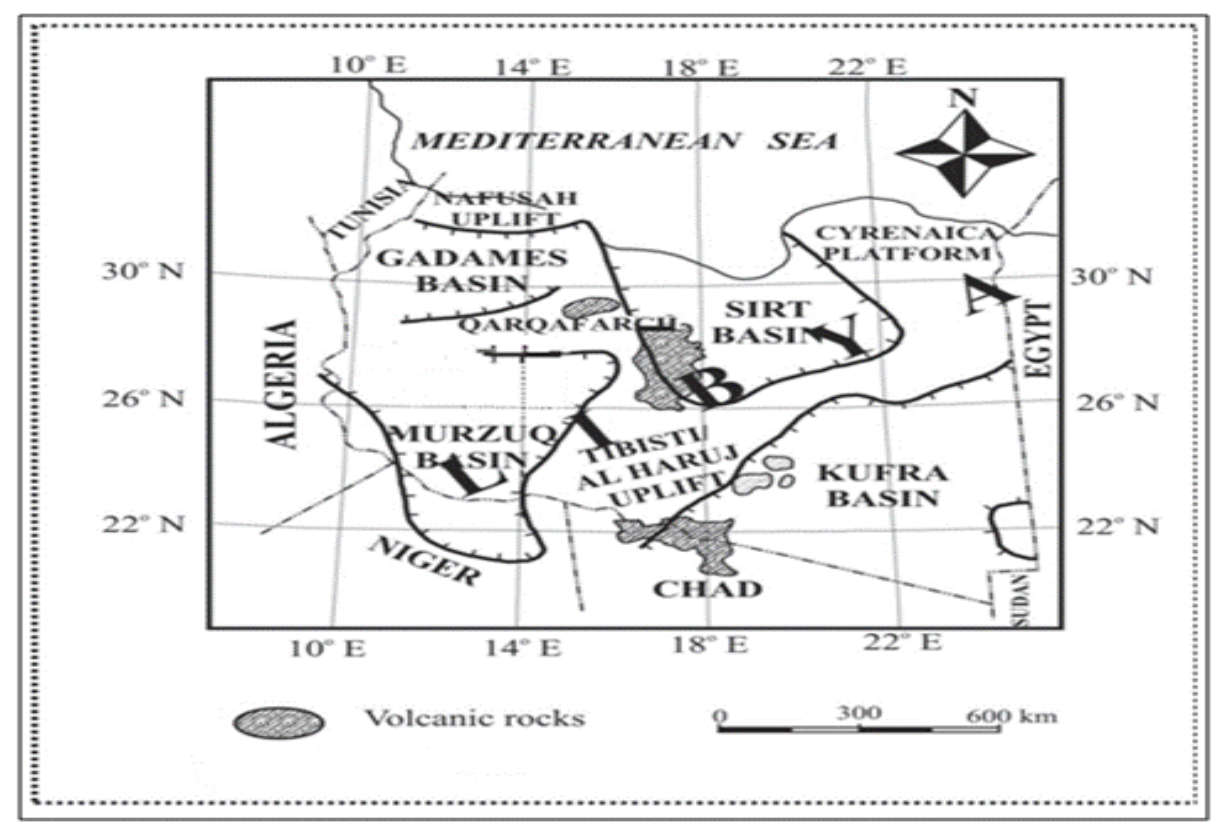

Fig. 1 Location Map of the Sedimentary Basins of Libya (After Fello [3])

This Basin has different concessions containing some oil fields. Each field has some wells drilled for the evaluation of subsurface geology and hydrocarbon potentialities of the Cambro-Ordovician Hawaz Formation intervals drilled by Repsol Oil Operations [4]. J field is one of the oil fields in concession NC186 that was encountered by ten exploratory and development wells, distributed in the field ( $\mathrm{J}$ NC186) on the northwestern flank of the Murzuq basin, southwest part of Libya (Fig. 1 and 2). The investigated $\mathrm{J}$ oil field lies between the latitudes $26^{\circ} 45^{\prime}$ and $26^{\circ} 50^{\prime} \mathrm{N}$ and longitudes $12^{\circ}$ $32^{\prime}$ and $12^{\circ} 36^{\prime} \mathrm{E}$ as shown below in (Fig. 2 and $3)$.

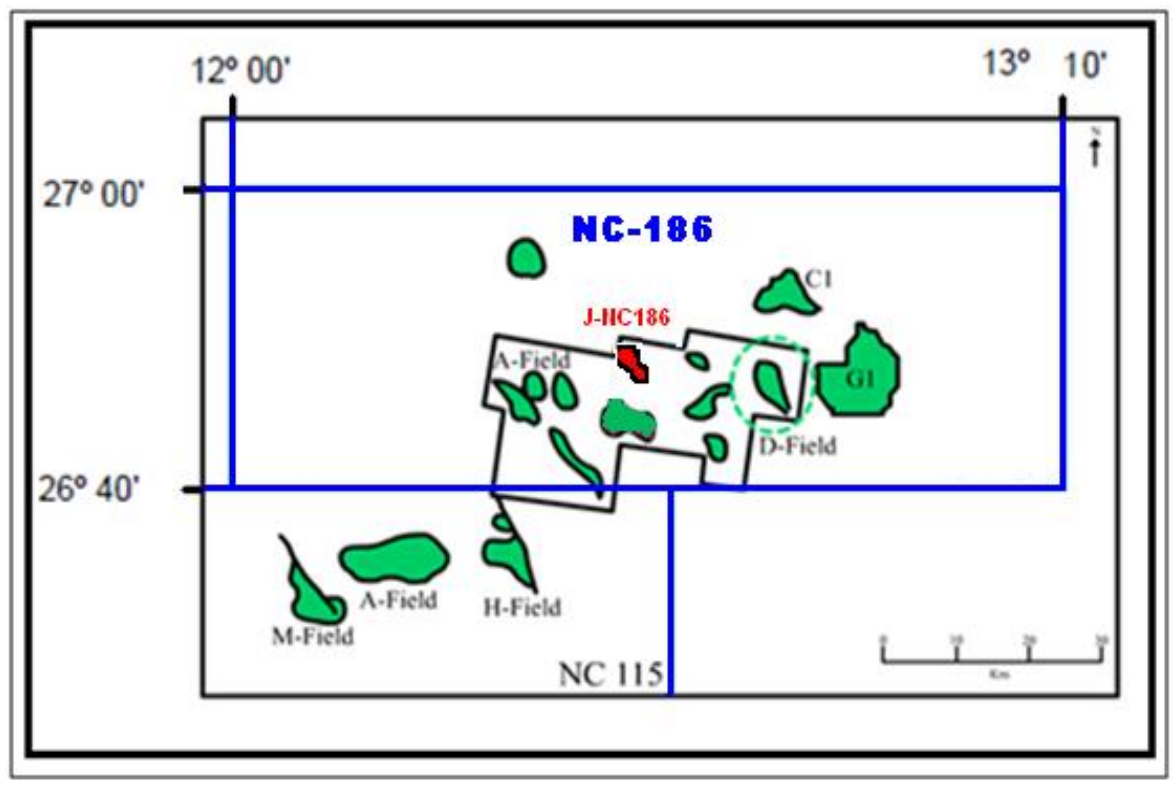

Fig. 2 Location map of J oil field, concession 186

Generally, the petroleum system is represented by structural Hawaz paleo-high created during the post Hawaz erosional event.
The main regional seal is the Silurian Tanezzuft shale Formation, and the basal Tanezzuft hot shale member acts as the main source rock in the 
area of study. This formation is considered the main target.

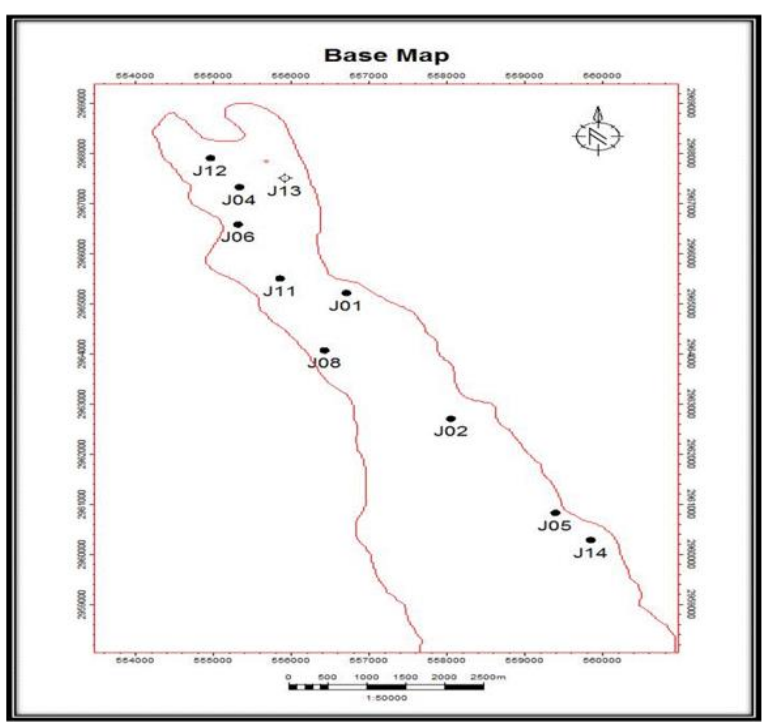

Fig. 3 location map of $\mathrm{J}$ oil field, concession 186, Murzuq basin

This paper is devoted to study the hydrocarbon potentialities of Hawaz Formation in $\mathbf{J}$ oil field through analysis of the available well $\log$ data. A comprehensive analytical formation evaluation has been applied using interactive petro-physics (IP) software. The well log data comprise resistivity, sonic, neutron, density, nuclear magnetic resonance, spontaneous potential, caliper, gamma ray and natural gamma ray spectrometry logs.

\section{General Geologic and Structural Settings}

Murzuq basin is located on SW Libya and forms one of several intracratonic sag basins. The structural fabric imparted to the North African continental lithosphere during the late Proterozoic, Pan-African event has played an important role in controlling the subsequent structural and stratigraphic evolution of the basin. Early Palaeozoic tectonics created a series of NNW trending arches and sub-basins across North Africa, which filled with clastic continental and shallow marine deposits and transgressive open marine facies. Early Palaeozoic tectonism effectively controlled the distribution of late Ordovician reservoirs and distribution of Silurian "Hot Shale" which onlap early- formed fault blocks $[3,4]$.

The structure of the Murzuq basin is quite simple. The sub-horizontal or gently dipping strata is faulted and the faults are most frequently parallel to the axis. Tectonic movements affected the basin to a greater or lesser degree from middle Palaeozoic (Caledonian) to PostOligocene (Alpine) times [6].

Caledonian, Hercynian and Alpine tectonic events affected this basin evolution, specially Caledonian and Hercynian orogenies [6]. The Caledonian orogeny started in the Upper Silurian and persisted through the lower part of the Lower Devonian,. This has been provided in several localities in the south of the Ghadames Basin, in the Murzuq basin and also in the Kufra basin (Fig. 4).

The stratigraphic column of Murzuq basin ranges from the Pre-Cambrian to the Quaternary (Fig. 5). The maximum thickness in the basin center doesn't exceed $4000 \mathrm{~m}$. Hawaz formation rests conformably over the Ash Shabiyat formation. Both formations are cut by an erosive surface recognizable in outcrop and subsurface $[7,8]$. This surface is related to a glacial period lasting from Caradocian to Upper Ashgillian times. The deposition of the overlaying Melaz Shuqran formation was controlled by a prominent palaeo topography including deeply incised valleys.

Hawaz formation has been described by Pierobon [9] as "typically consisting of crossbedded, quartizitic sandstone with kaolinitic and thin shaley intercalations. Tigillites-bioturbated levels and ripple marks are conspicuous. The formation thickness ranges from $50 \mathrm{~m}$ (at Dor $\mathrm{Al}$ Qussah) to $300 \mathrm{~m}$ (at Al Qarqaf) in outcrops, and $30 \mathrm{~m}$ to $230 \mathrm{~m}$ in the subsurface. Palynological studies of this formation strongly indicate a Middle Ordovician (Llanvirnian-Llandeilian) age for the whole of the Hawaz formation, this is based on palynological data from Bras petro type well C1-NC58 [9].

\section{Well logging data analysis technique}

The processing of the well logging data in this study has been carried out utilizing constructing two cross-plots (Pickett and Hingle) for deriving formation water resistivity $\left(R_{w}\right)$, cementation factor $(m)$ and matrix parameters $\left(\rho_{m a}, \Delta t_{m a}\right)$.These parameters were used as input parameters for the interactive petrophysics software to evaluate Hawaz reservoir. The pay flag were computed using Vshale cut-off $40 \%$, Porosity cut off $10 \%$ and Sw cut-off $50 \%$. These cut-off percent's were determined from the 
inspection of the logs and cross plots of the porosity versus Vshale. The output results are presented in the form of litho-saturation cross plots and maps.

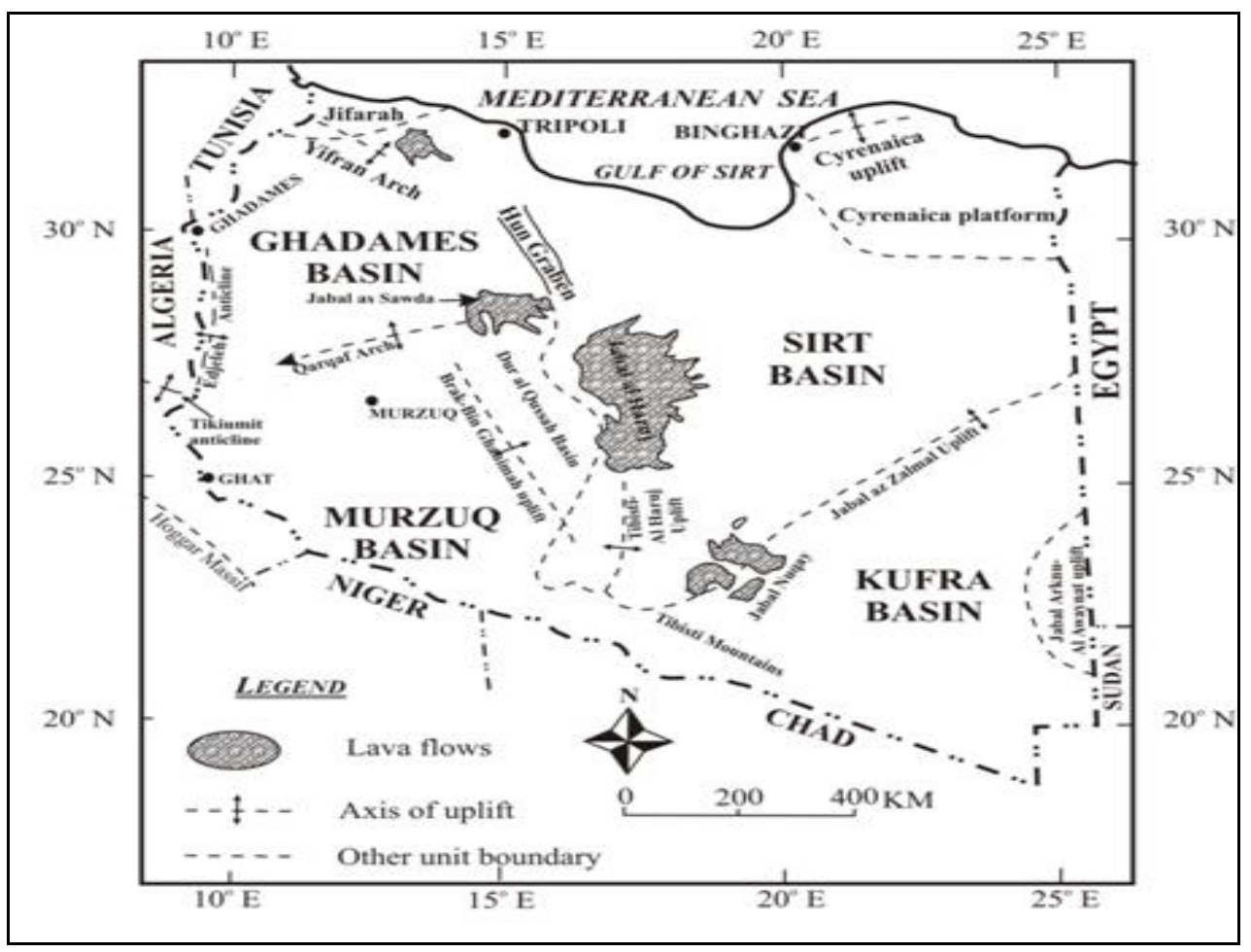

Fig. 4 Location Map showing the general tectonic framework of Libya (After Fello, 2001)

\section{Applications}

The pickettcross-plot [10] is one of the simplest and most effective cross-plot methods in use. This technique is based on the observation that true resistivity (Rt) is a function of porosity $(\varnothing)$, water saturation $\left(S_{w}\right)$, and cementation factor (m). On the plot, a zone with constant water saturation will have data points along a single straight line trend. The slope of the straight line representing $\mathrm{SW}=100 \%$ represent $-\mathrm{m}$ and its intersection with $100 \% \Phi$ is aRw. Figures 6 and 7 represent the Pickett plot for Hawaz formation in wells $\mathrm{J} 11-\mathrm{NC} 186$ and $\mathrm{J} 13-\mathrm{NC} 186$. It was found from the cross-plots that the average value of $\mathrm{Rw}$ equals to $0.31 \Omega \mathrm{m}^{2} \mathrm{~m}^{-1}$, which is correletable with that obtained by core sample data executed by Repsol oil operation. It was also found that $m$ is equal 2 .

On the other hand, matrix parameters $\left(\rho_{m a}, \Delta t_{m a}\right)$ have been obtained from Hingle cross-plot. In this study, the matrix values have been determined by the intersection of
$\mathrm{SW}=100 \%$ line and the horizontal axis. Figures 8 and 9 represent Hingle cross plot for Hawaz formation for J13-NC186 and J1-NC186 wells respectively. The results indicated that $\rho$ ma value is $2.66 \mathrm{~g} \mathrm{cc}^{-1}$ and $\Delta t_{m a}$ is $55 \mu \mathrm{sec} / \mathrm{feet}$. Dia porosity cross plot between $\rho b$ versus $\Phi \mathrm{N}$ is used for evaluating matrix lithology and porosity. The lithological facies for Hawaz formation in J4NC186 well consists mainly of sandstone matrix (Fig. 10). This sandstone is characterized by coarsening upward facies from horizon $\mathrm{H} 8$ at the bottom level to horizon $\mathrm{H} 1$ at the top (Fig. 11).

\section{IP output results}

The IP output results were presented in the form of lithosaturation cross plots for Hawaz Formation in the study area. This formation was subdivided into eight subzones $\mathrm{H} 1, \mathrm{H} 2, \mathrm{H} 3$, H4"H4a-H4b-H4c", H5, H6"H6a-H6b-H6c", H7 and H8. These subzones have its own petrophysical parameters (Vsh, Sw, Sh and $\Phi)$. 


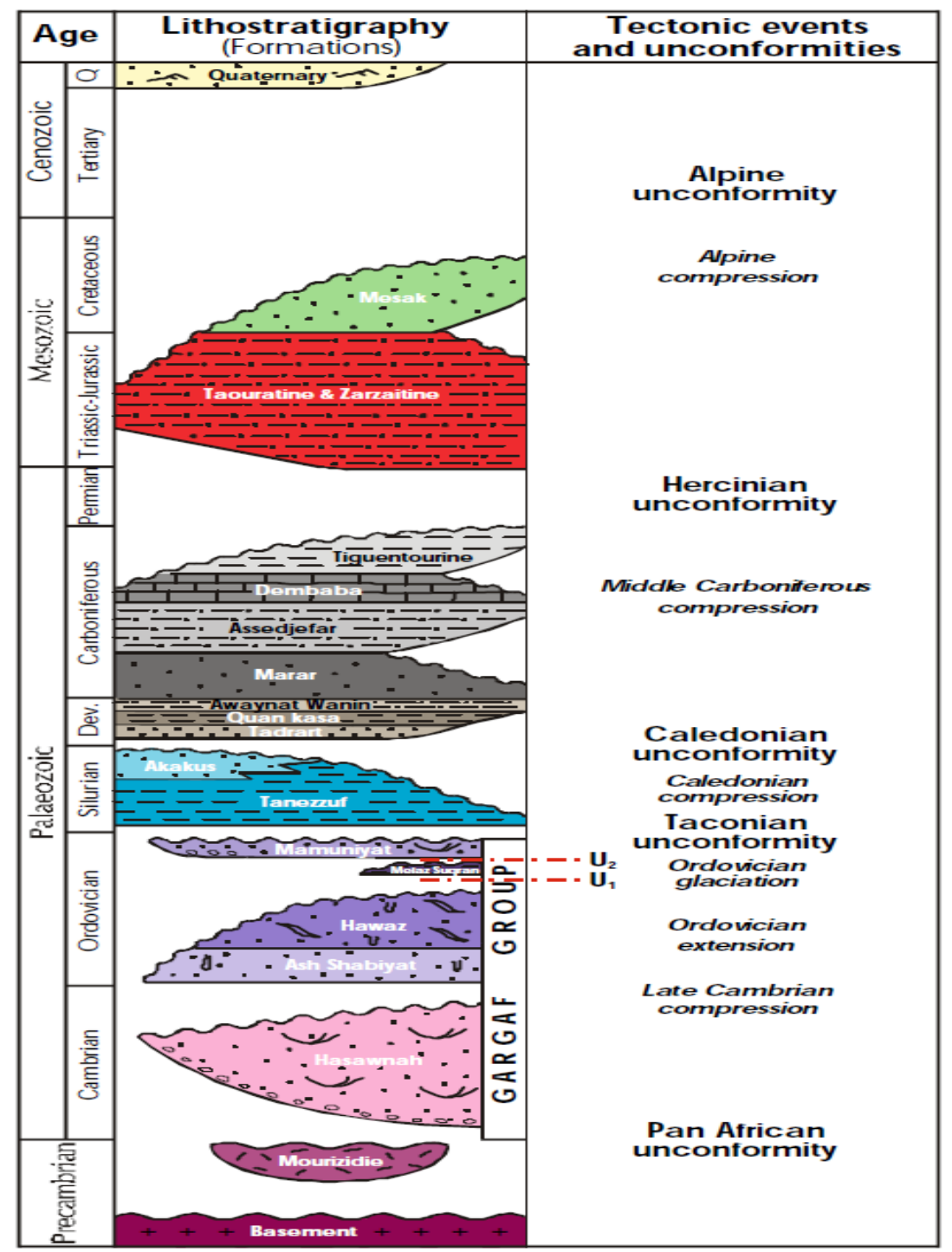

Fig. 5 Stratigraphic column of the Palaeozoic, Mesezoic and Cenozoic successions in NC186, NW Murzuq basin, SW Libya , (modified from Davidson et al. [2])

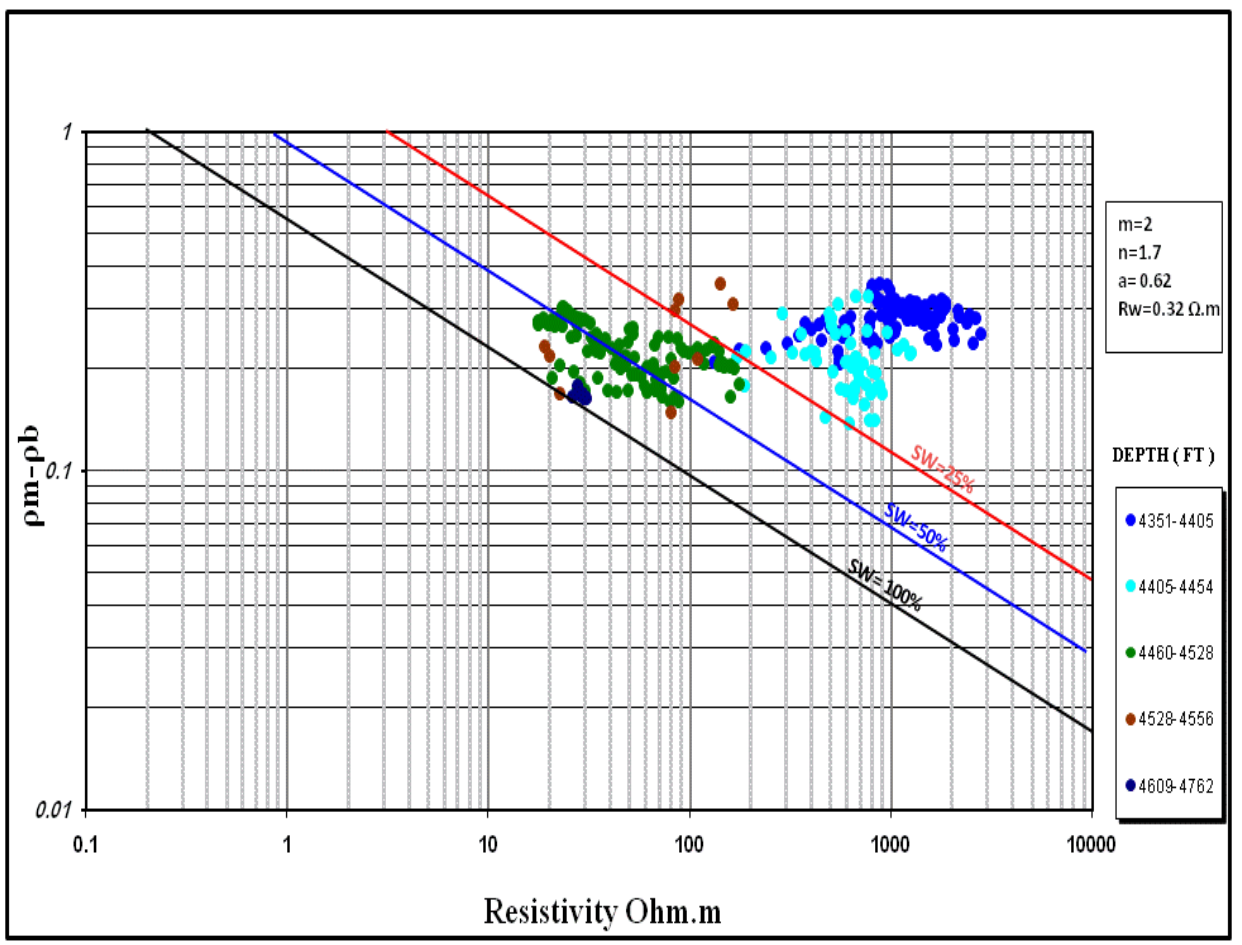

Fig. 6 Pickett plot for Hawaz Formation for J11-NC186 well, J oil field 


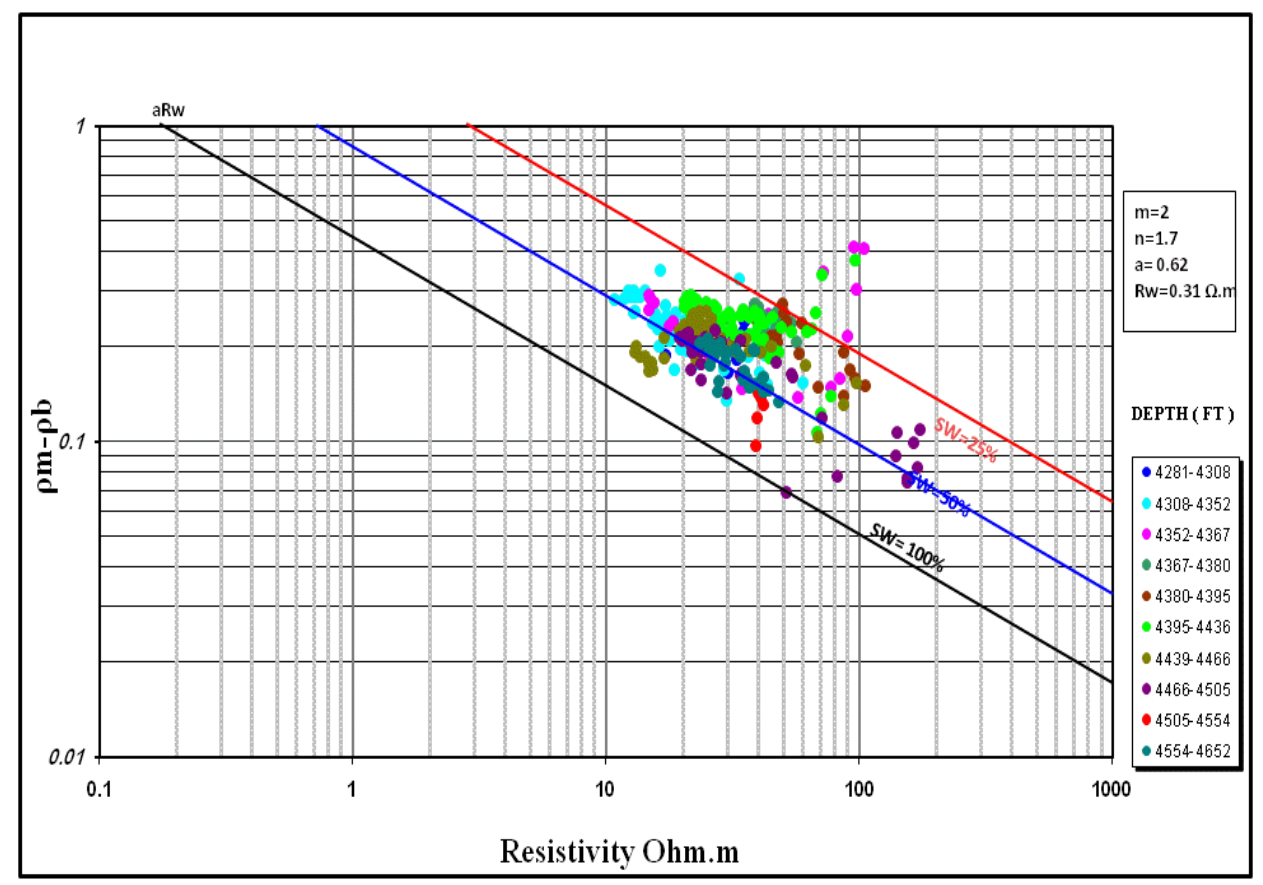

Fig. 7 Pickett plot for Hawaz Formation for J13NC186 well, J oil field.

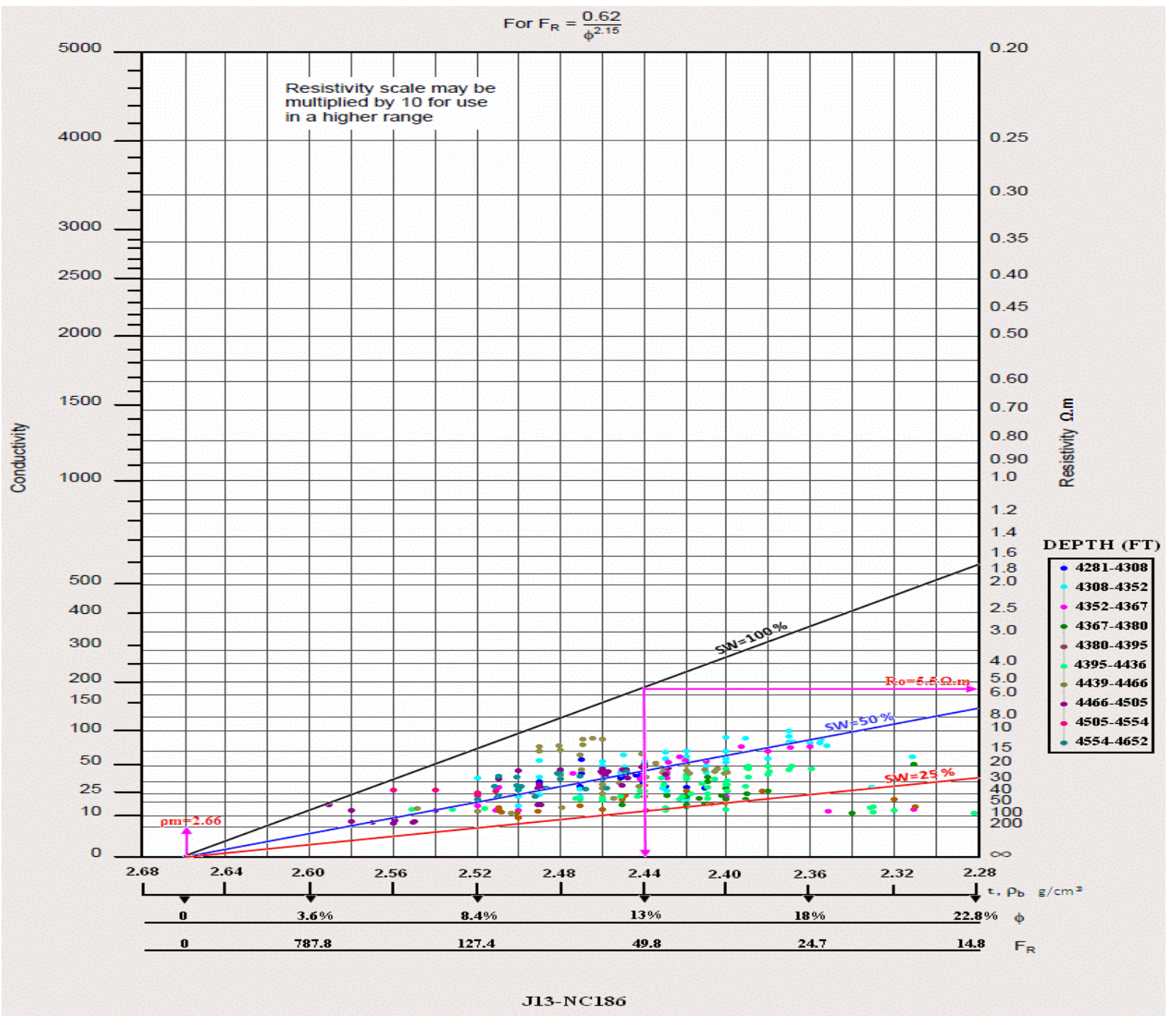

Fig. 8 Hingle cross-plot for Hawaz Formation at J13-NC186 


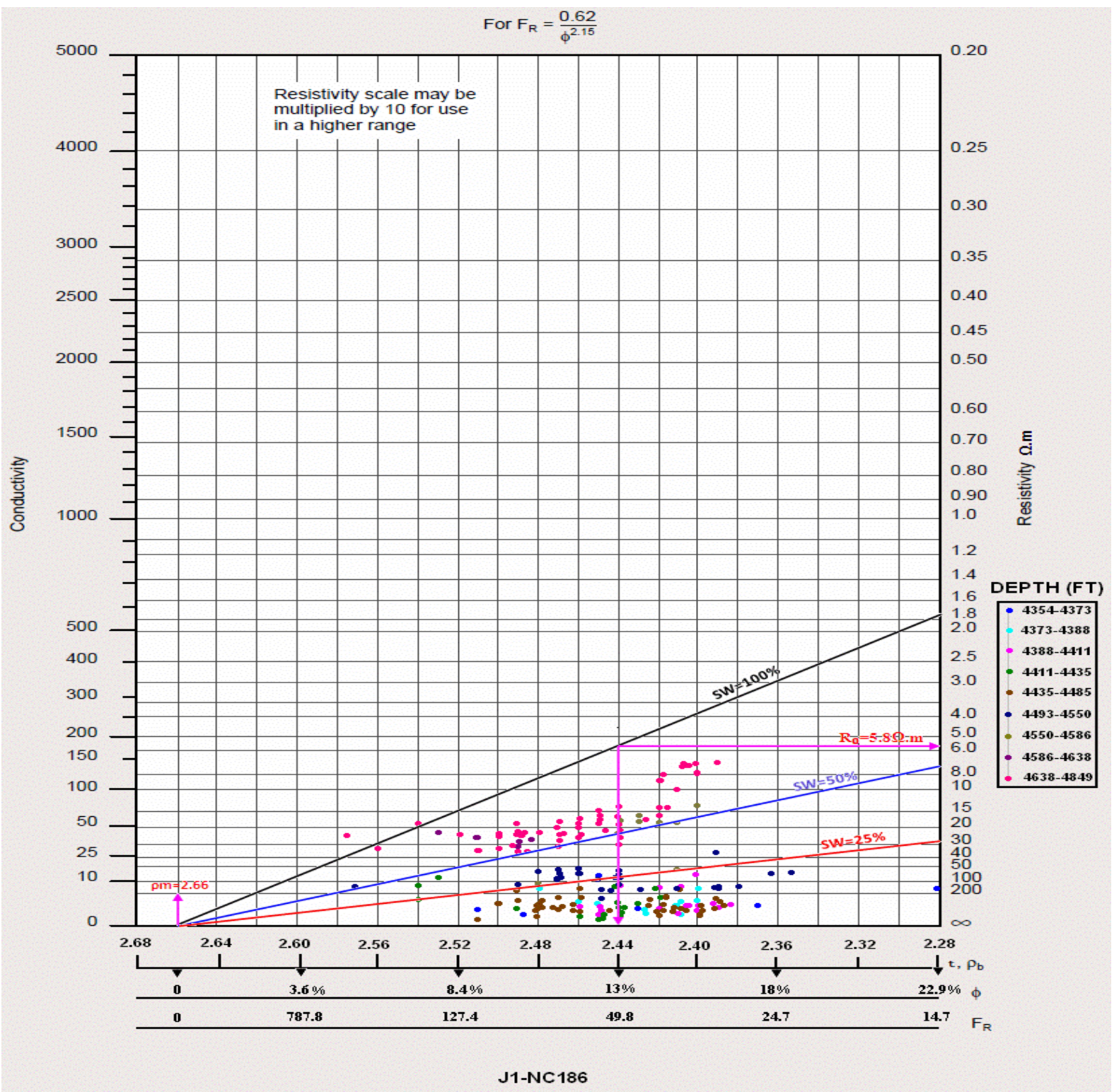

Fig. 9 Hingle cross-plot for Hawaz Formation at J1-NC186

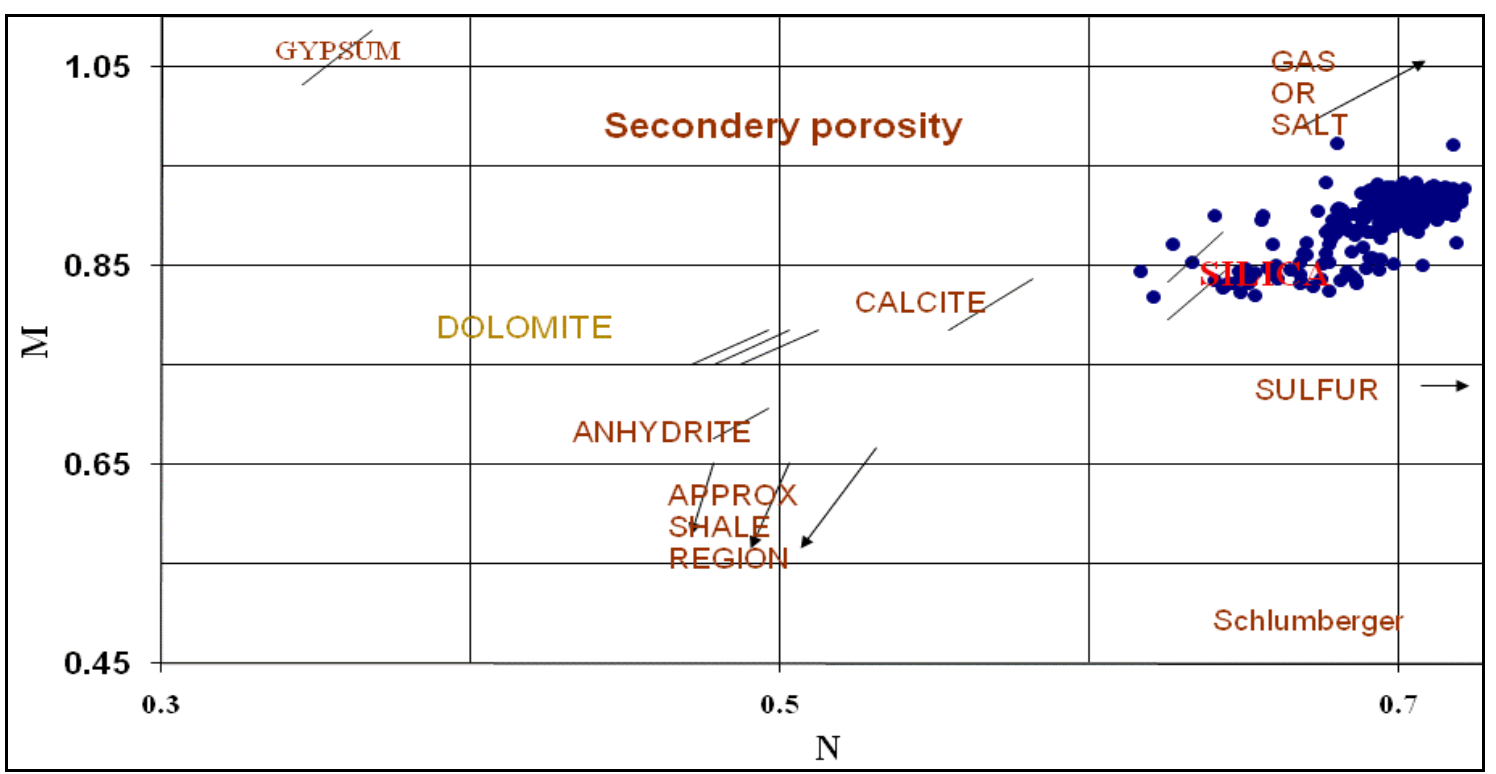

Fig.10 porosity $\rho b$ vs Øn cross-plot for Hawaz Formation for J4-NC186 well, J oil Field 


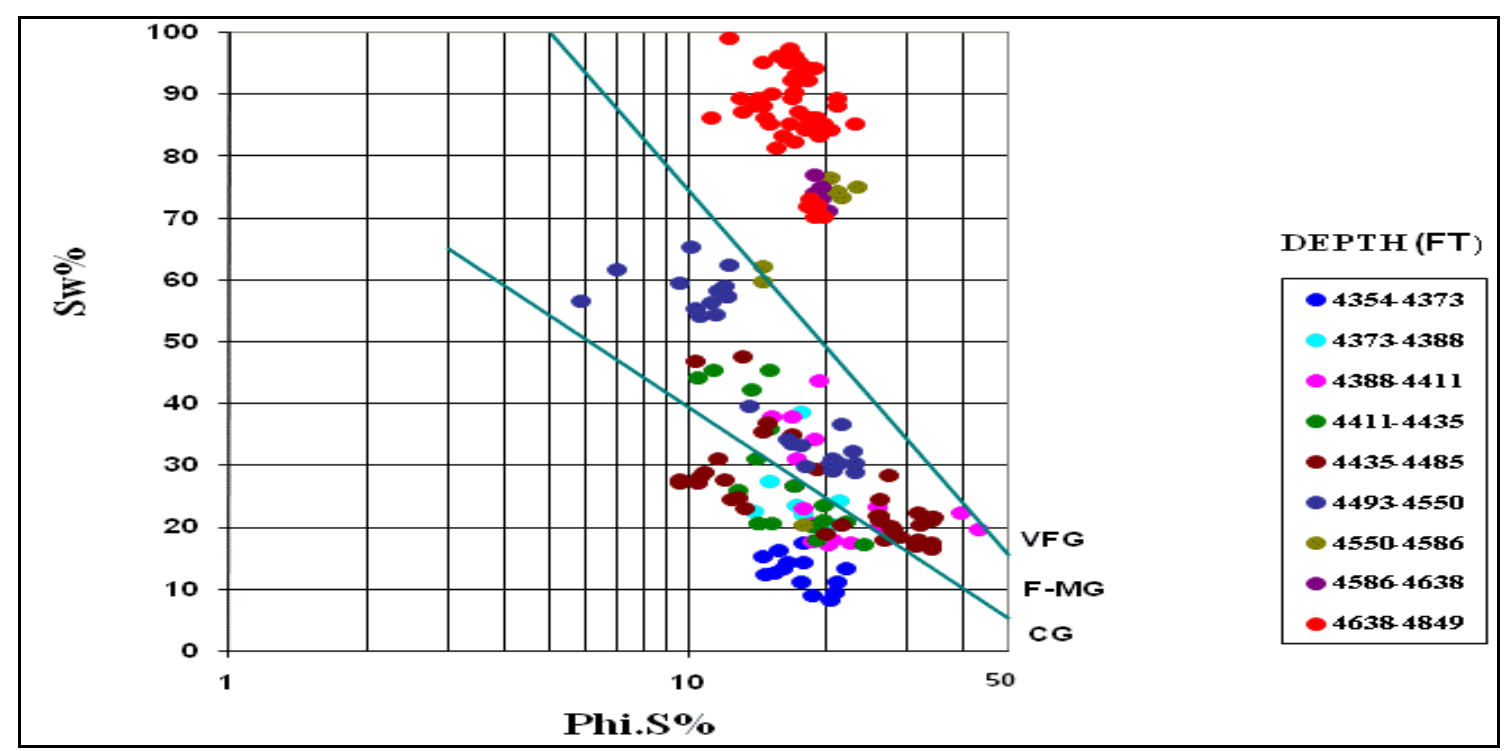

Fig. 11 Sw vs $\Phi$ showing upward coarsening sequence, for Hawaz Formation at J1-NC186, J oil Field

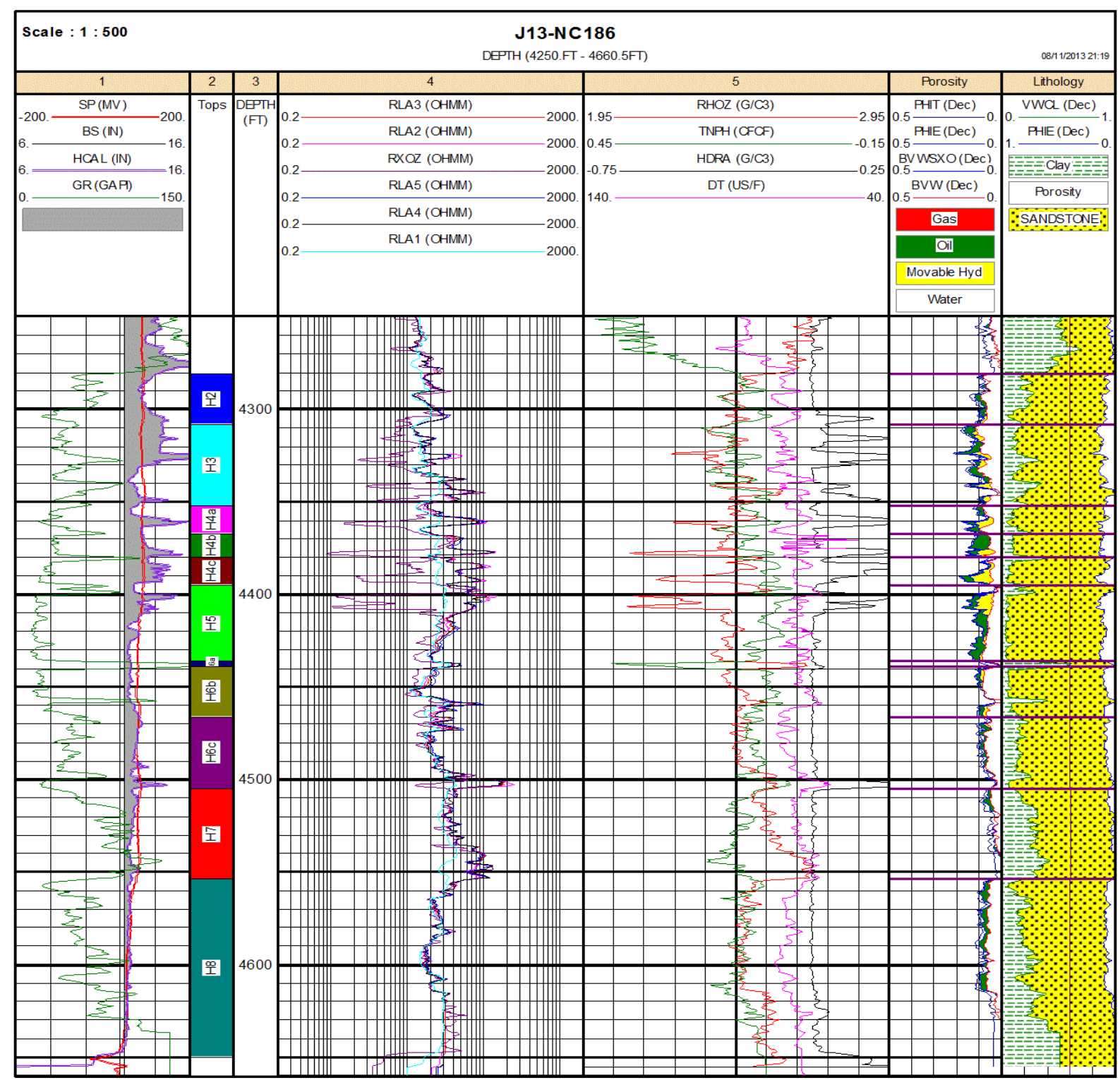

Fig. 12 IP results for Hawaz Formation, J13-NC186 well. J Oil Field 


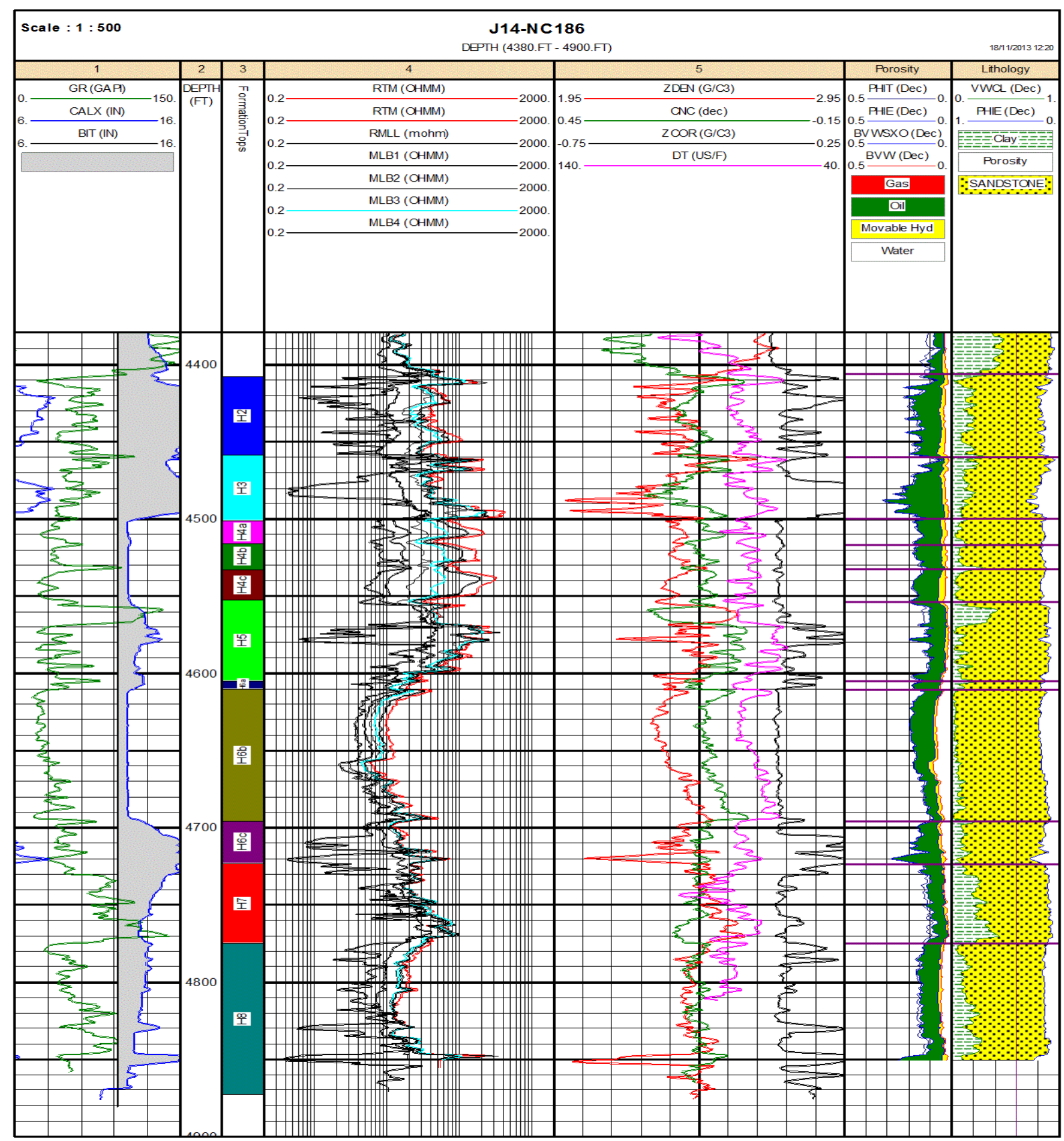

Fig. 13 IP results for well J14-NC186, J Oil Field

The calculated shale volume Vsh for Hawaz formation in J13-NC186 well (Fig. 12) ranges from $5.7 \%$ to $19.6 \%$ with average $10.9 \%$. The effective porosity ranges from $10.1 \%$ to $15 \%$ with average $13 \%$. Water saturation ranges from $31 \%$ to $75.7 \%$ with average $56 \%$. The top of Hawaz formation is $4281 \mathrm{ft}$ with a gross thickness of $369 \mathrm{ft}$. and net pay thickness is $98 \mathrm{ft}$. It is well known that $\mathrm{H} 4$ and $\mathrm{H} 5$ are potentially the most productive subzones. On the other hand, the calculated shale volume of J14-NC186 well (Fig. 13) ranges from $5.2 \%$ to $19.2 \%$ with average $11.8 \%$, the effective porosity ranges from $11.7 \%$ to $19.3 \%$ with average $15.3 \%$, the water saturation ranges from $12.9 \%$ to $41 \%$ with average $26 \%$.

The top of Hawaz formation is at $4408 \mathrm{ft}$ with a gross thickness of $465 \mathrm{ft}$. and net pay thickness is $388 \mathrm{ft}$. From H3 to H5 are potentially the most productive subzones. The litho-saturation crossplot of well J1-NC186 (Fig. 14) displays that the calculated shale volume ranges from $0.2 \%$ to 4.5 $\%$ with average $2.6 \%$, the effective porosity ranges from $11 \%$ to $24.7 \%$ with average $14 \%$, the water saturation ranges from $9 \%$ to $75 \%$ with average $53 \%$. The top of Hawaz formation is at 
$4354 \mathrm{ft}$ with a gross thickness of $495 \mathrm{ft}$. and net pay thickness $294 \mathrm{ft}$. It is indicated also that subzones $\mathrm{H} 3, \mathrm{H} 4$ and, $\mathrm{H} 5$ are potentially the most productive zones (Fig. 14).

\section{Areal distribution of Hawaz reservoir}

The deduced petrophysical parameters are represented by a number of isoparameteric maps showing the lateral distribution of Hawaz Formation. The gross reservoir thickness contour map (Fig. 15) shows that the maximum recorded reservoir thickness 558ft at J5-NC186 well, while it decreases gradually NW and west ward recording the minimum value of $304 \mathrm{ft}$ at the J6NC186 well.

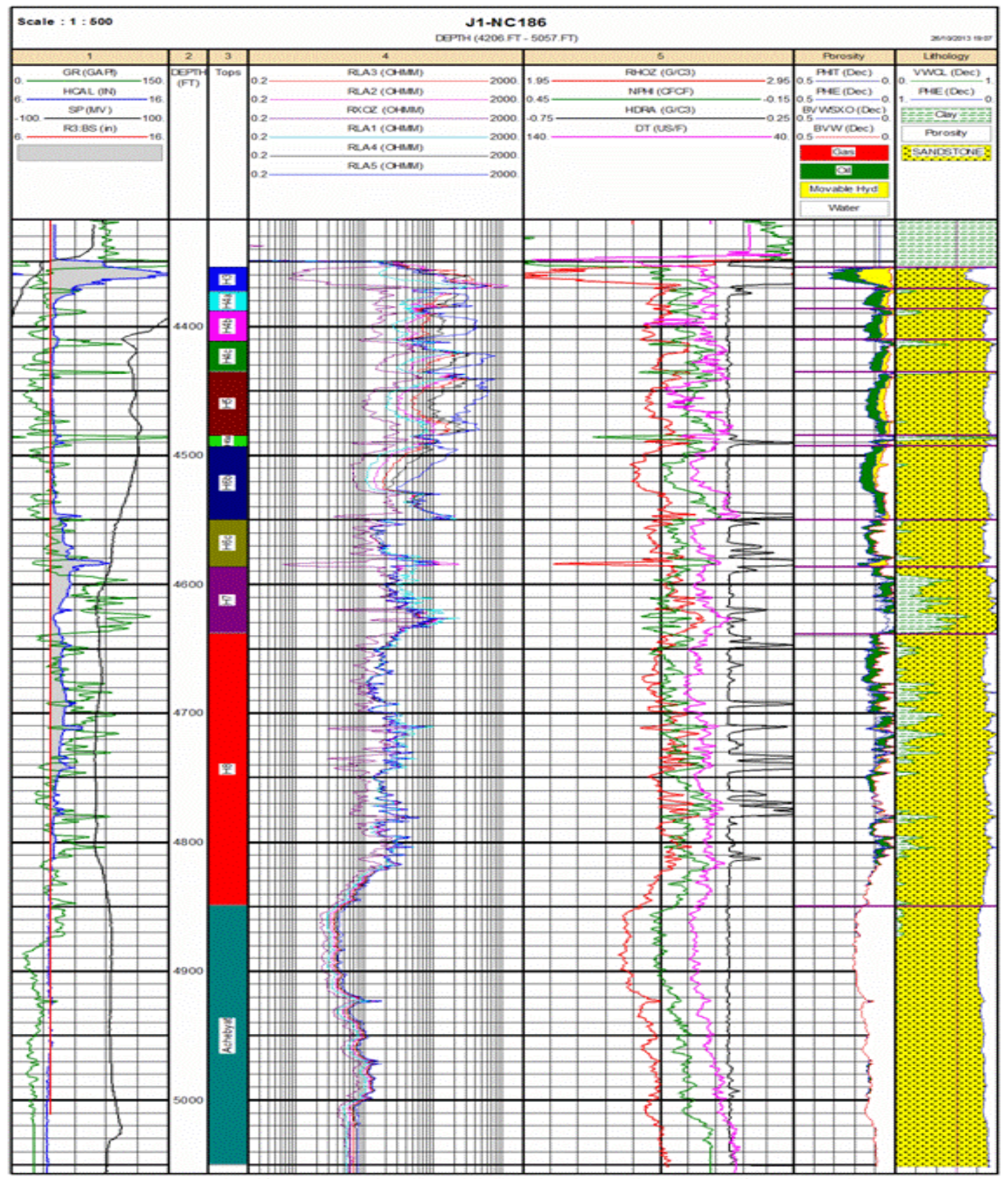

Fig. 14 IP results for well J1-NC186, J Oil Field 


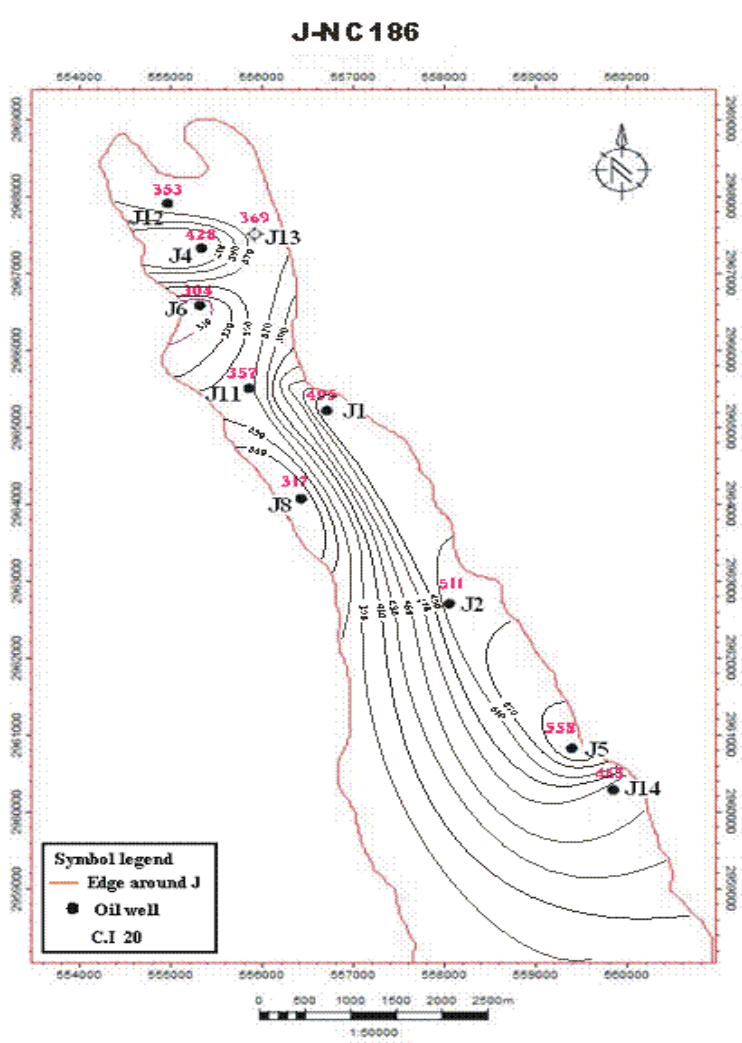

Fig.15 Gross thickness contour map for Hawaz reservoir in J-NC186 Concession

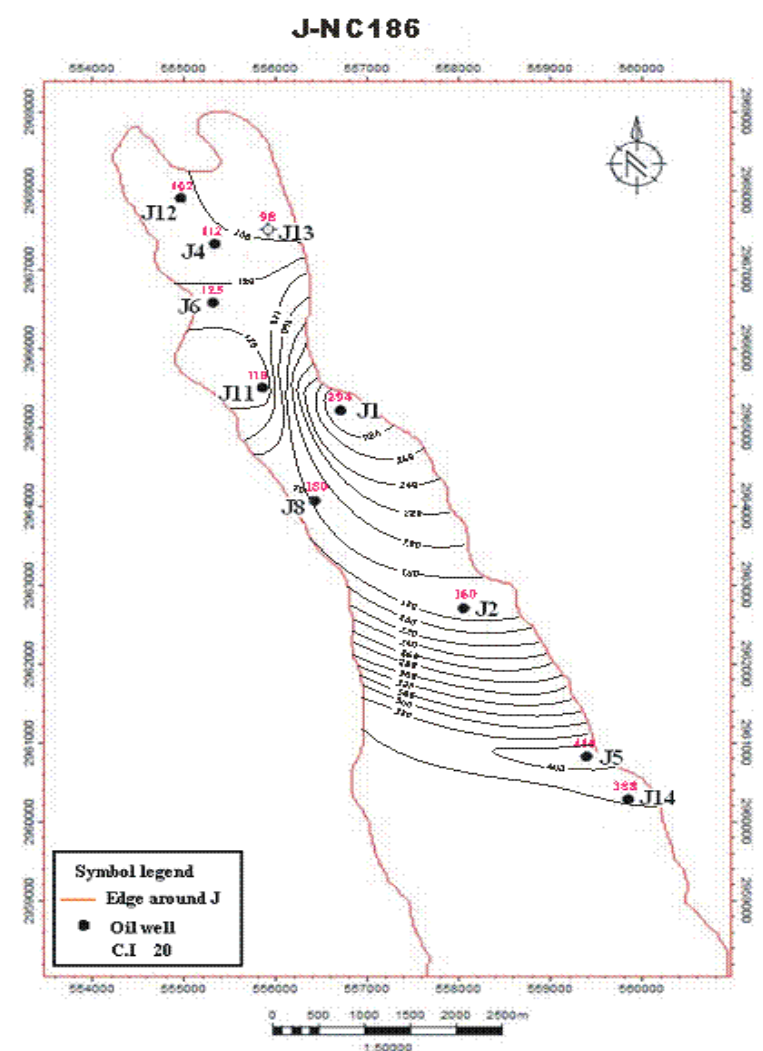

Fig. 16 Net Pay thickness contour map for Hawaz reservoir in J-NC186 Concession

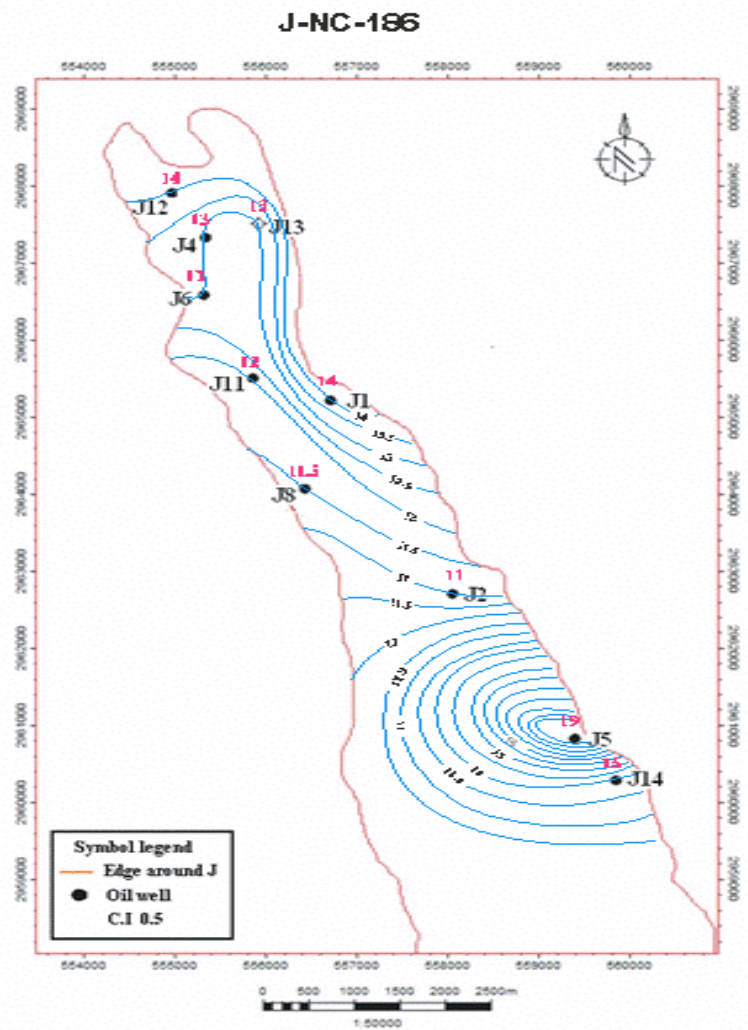

Fig. 17 Average effective porosity contour map for Hawaz reservoir in J-NC186 Concession

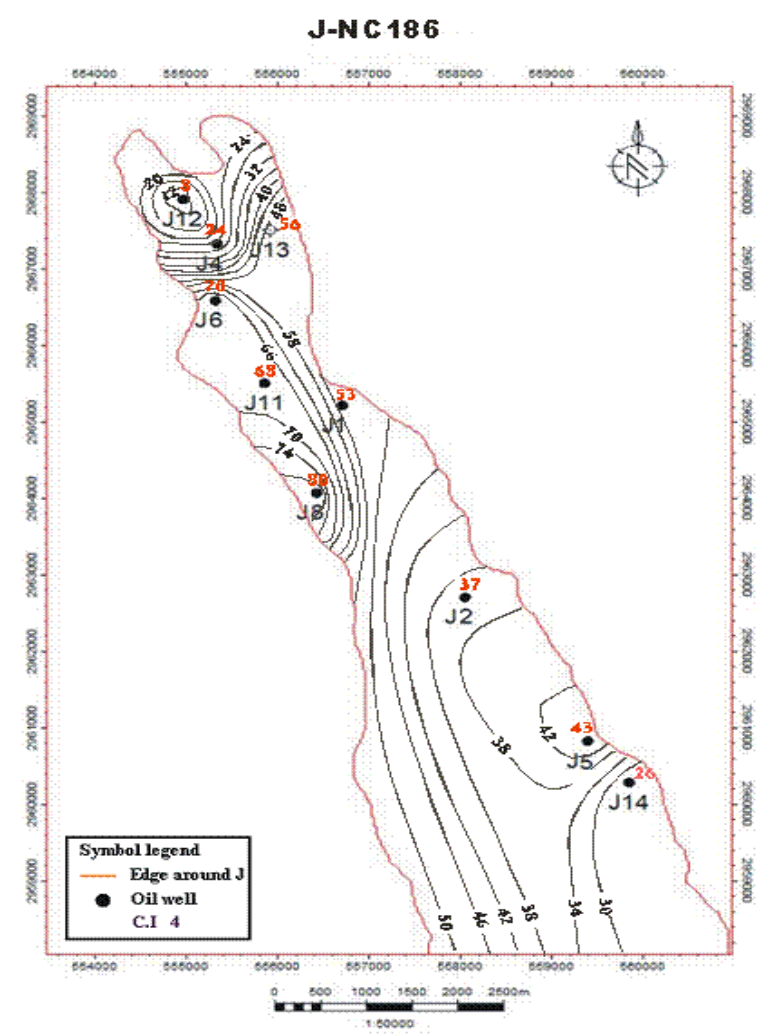

Fig. 18 Average water saturation contour map for Hawaz Reservoir in J-NC186 Concession 


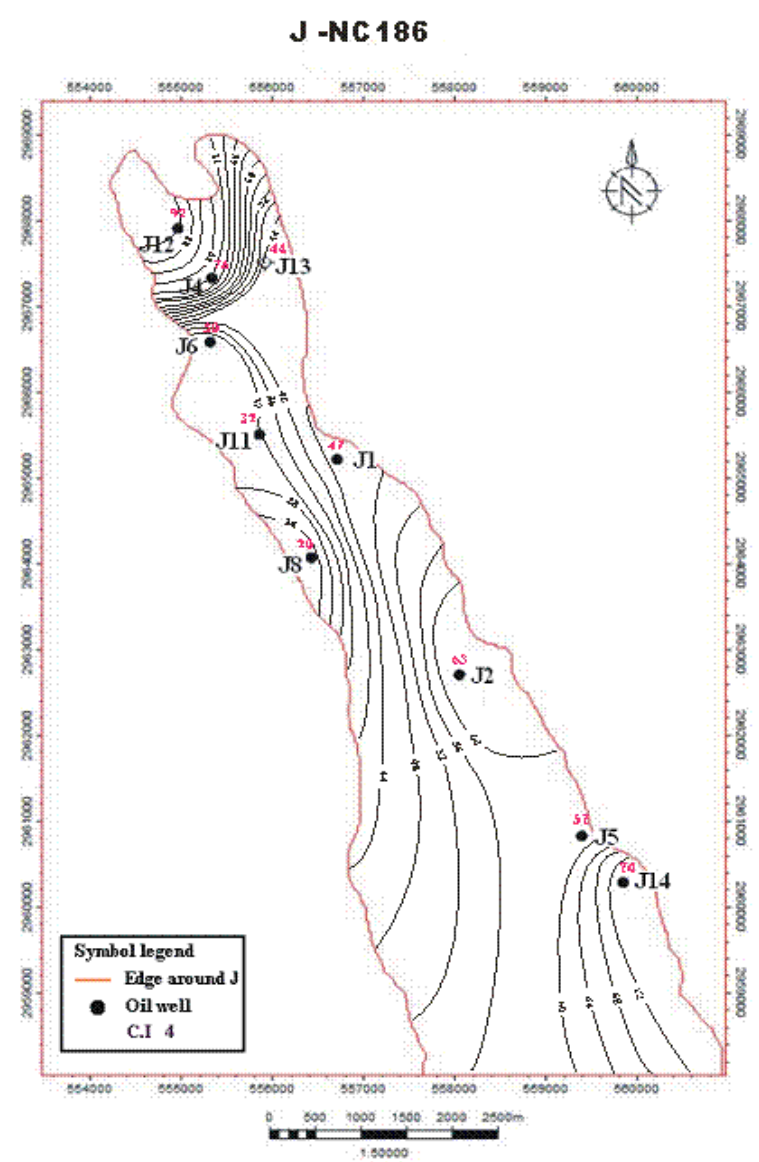

Fig.19 Average oil saturation contour map for Hawaz Reservoir in J-NC186 Concession

The net reservoir thickness contour map indicates a maximum recorded thickness of $410 \mathrm{ft}$ at well J5-NC186 (Fig. 16), while it decreases gradually from the center to the north and recording the minimum value of $98 \mathrm{ft}$ at $\mathrm{J} 13$ NC186 well. The effective porosity contour map of the Hawaz reservoir shows a regular pattern of distribution with a general increasing towards SE of the area (Fig. 17), recording a maximum value of $19 \%$ at well $\mathrm{J} 5-\mathrm{NC} 186$. The water saturation contour map of the reservoir illustrates a considerable distribution pattern with a general increasing in center of the study area (Fig. 18), and recording a maximum value of $80 \%$ at well J8-NC186. This value decreases gradually towards NW-SE of the study area recording a minimum value of $8 \%$ at well $\mathrm{J} 12-\mathrm{NC} 186$. The oil saturation contour map displays a maximum value at well J12-NC186 while it decreases to a minimum value at well J8-NC186 (Fig. 19). This oil is mainly concentrated at the horizons $\mathrm{H} 4$ and $\mathrm{H} 5$ as indicated from well $\log$ responses and litho-saturation cross-plots.

\section{Conclusions}

This paper has been carried out to study and evaluate the petrophysical characterisitics of Hawaz formation in $\mathbf{J}$ oil field of concessions NC186. The conclusions which can be extracted are as follows:

- The analytical formation evaluation reveals that the hawaz reservoir is mainly clean sandston. This sandstone represents coarsening upward facies.

- $\mathrm{H} 4$ and H5 subzones are potentially the most productive in Hawaz formation as indicated from the litho-saturation cross-plots.

\section{References}

[1] D. Thomas, Geology, Murzuq oil development could boost S. W. Libya prospects. Oil and Gas Journal, March 6 (1995) p. 41-46

[2] L. Davidson, S. Beswetherick, J. Craig, M. Eales, A. Fisher, A. Himmali, J. Jho, B. Mejrab, J. Smart, The structure,stratigraphy and petroleum geology of the Murzuq basin, southwest Libya. In: M.A. Sola and D. Worsley (Eds). Geological exploration in Murzuq Basin. Elsevier Science, Amsterdam (2000) p. 295-320

[3] N.M. Fello, B.R. Turner, Provenance analysis, tectonism and shifting depositional system in the NW part of the Murzuq Basin, Libya: implication for hydrocarbon prospectivity. 21st International Association Sedimentology (IAS) meeting of Sedimentology, Abstr., Davos, Switzerland (2001)

[4] Repsol oil operation, field $\mathrm{H}$ development plan, Repsol exploration Murzuq S A (Internal report ) (2005)

[5] E. Klitzsch, Stratigraphic section from the type areas of Silurian and Devonian strata at Western Murzuq Basin, Libya. In: J. J. Williams (Ed.). Geology Archaeology and Prehistory of the southwestern Fezzan, Libya. Petrol. Explore. Soc. Libya, 8th Annu. Field Conf. (1969) p. 83101

[6] E. Bellini, D. Massa, A stratigraphic contribution to the Palaeozoic of southern basins of Libya. In: Salem M. J. and Busrewil M. T (Eds.). The Geology of Libya. Academic press, London, Vol. 1 (1980) p. 3-56

[7] A. Aziz, Stratigraphy and hydrocarbon potential of the Lower Palaeozoic succession of License NC-115, Murzuq basin, SW Libya. In: M.A. Sola and D. Worsley (Eds). Geological exploration in Murzuq Basin. Elsevier Science, Amsterdam, (2000) p. 349-368

[8] A. Khoja, T. Gashgesh, M. Swedan, B. Garea, S. Ghnia, Paleorelieves fósiles del Ordovícico en la Cuenca de Murzuq, Sudoeste de Libia. Boletín 
de Informaciones Petroleras 64 (2000) 14-31

[9] E.S.T. Pierobon, Contribution to the stratigraphy of the Murzuq Basin, SW LIBYA. In: Salem, M.J. and Belaid, M.N (Eds.). The geology of
Libya, Academic Press London, Vol. V (1991) p. 1767-1784

[10] G.R. Pickett, Practical formation evaluation Golden Colorado (1972)

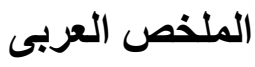

جودة الخزان لمتكون حواز، حقل J، الامتياز NC186، شمال غرب حوض مرزق، جنوب غرب ليبيا

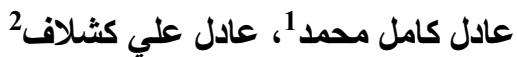

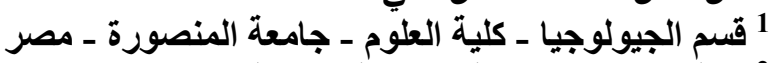

2 كلية الموارد الطبيعية ـ جامعة الزاوية جلية ـ اليبيا

البحث الحالى يعنى بتقييم الخصائص البتروفيزيائية لمتكون حواز بحقل J بالامتيازNC186 داخل

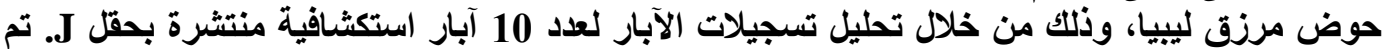

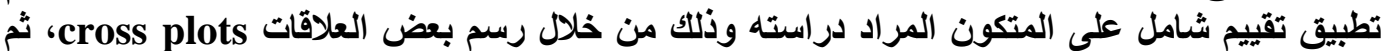

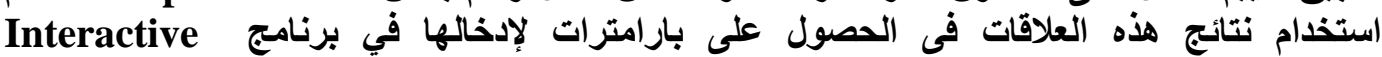
Petrophysics software (IP)

السوائل التي يحتويها هذا المتكون.

هذه النتائج تم رسمها في صورة Litho-saturation cross plots والتي أظهرت أن النمئ السحنة

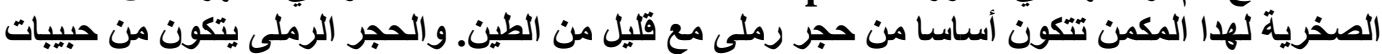

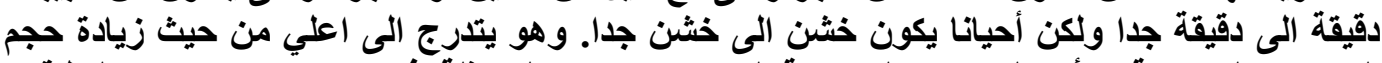

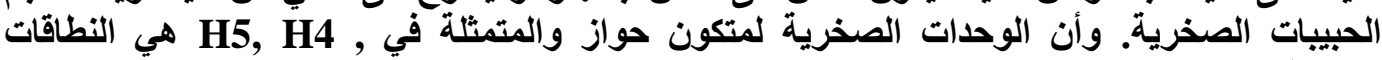

المنتجة. 